\title{
PERVERSE MANIFESTATIONS IN A MELACHOLIC STRUCTURE
}

Larissa Bastiani Roggia and André Goettems Bastos

Larissa Bastiani Roggia Contemporâneo: Instituto de Psicanálise e Transdisciplinaridade, Porto Alegre/RS, Brasil.

André Goettems Bastos Pontifícia Universidade Católica do Rio Grande do Sul (PUC-RS), Programa de Pós-Graduação em Psicologia, Porto Alegre/RS, Brasil.
ABSTRACT: This study aims to describe the expression of perverse traits operating in a melancholic personality structure. The definition of the basic concepts of structure, organization of personality and character traits is made. The characteristics of the melancholic structure and perverse organization are described and through the study of a single case, we seek to demonstrate the psychodynamics of a melancholic personality structure and identify the manifestation of perverse traits. The clinical discussion focuses on the acting of the perverse traits over melancholy. The paper demonstrates the importance of understanding these dynamics and diagnostic aspects to the clinical practice in psychoanalysis. Furthermore, it was possible to conclude that perverse manifestations may occur in different personality structures, not being exclusive of perverse organizations of the self.

Keywords: melancholy, perversion, sadism, masochism, psychoanalytic psychotherapy.

RESUMO: Manifestações perversas em uma estrutura melancólica. O presente trabalho busca descrever a manifestação de traços de funcionamento perversos em uma estrutura de personalidade melancólica. São definidos os conceitos de estrutura de base, organização da personalidade e traços de caráter. As características da estrutura melancólica e da organização perversa são descritas e, através de um estudo de caso único, busca-se demonstrar a psicodinâmica de uma estrutura de personalidade melancólica, bem como identificar os traços de caráter perversos manifestos. A discussão clínica enfoca a atuação de traços perversos na melancolia. Ao final, demonstra-se a importância da compreensão diagnóstica e dinâmica desses aspectos para a prática na clínica psicanalítica. Além disso, foi possível constatar que manifestações perversas podem ocorrer em diferentes estruturas de personalidade, não sendo exclusivas das organizações perversas do self.

Palavras-chave: melancolia, perversão, sadismo, masoquismo, psicoterapia psicanalítica.

DOI - http://dx.doi.org/10.1590/S1516-14982016002004 


\section{INTRODUCTION}

In psychoanalysis, we frequently come across similar character traits manifested in different patients who often do not share the same personality structure. This suggests that certain characteristics displayed by patients are not exclusive to the type of personality they present as they can be found in other structures. Perverse character traits constitute an example of such characteristics as they can be identified in several personality structures as well as in anestructures while not being necessarily linked to a perverse organization of personality.

The study of this issue intends to assist the psychodynamic understanding of patients, enabling a deeper diagnostic process. In order to understand this phenomenon, it is first necessary to address some fundamental concepts such as base personality structure, personality organization and character traits. An adequatecomprehension of theseaspects aims toavoid diagnostic confusion and consequent inadequate clinical decisions during treatment.

In this sense, the present study will outline the functioning of a melancholic personality structure and a perverse personality organization, seeking to highlight their particularities. For illustration purposes, a clinical case of a patient with melancholic functioning in which it is possible to notice the intense acting of perverse traits will be presented. These aspects will be discussed within the psychoanalytic theoretical framework, making it possible to debate different forms of manifestation of perverse character traits both within and outside the field of sexuality.

\section{DIAGNOSTIC-RELATED ISSUES}

Freud (1932/2006) used the term structure comparing it to a mineral which has been crystalized in a specific manner so that when broken it would shatter according to a pre-defined, previously imperceptible constitution, in spite of this predefined constitution being invisible in its natural state. In this sense, Freud explained his concept of personality structures, as they already possess certain pre-determined characteristics that will define the form by which pathological states will manifest themselves.

Bergeret (1998) retrieved Freud's concept, stating that as far as the issue of diagnosis is concerned it is necessary to perform a broader analysis of the subject. The analysis must consider deeper aspects such as fixation points, the genesis of parental relationship, the nature of the latent anguish, object-relations, the predominant defense mechanisms, and the way the symptom is expressed in the context of the subject's life. According to Bergeret, the two main base structures are neurosis and psychosis. The former includes the hysteric and obsessive structures while the latter encompasses the melancholic, paranoid and schizophrenic ones. 
At this point, it is necessary to open a parenthesis and make a comment on perversion, an important issue to the present study, which will be explored in the text under the guise of perverse organization. Bergeret understands perversion as an organization within the field of "anestructures", which in turn constitutes a separate unit encompassing specific configurations not included in neurosis and psychosis. Anestructures are also called borderline states between neurosis and psychosis. In such states, the subject has overcome the psychotic structure; nevertheless, he has not constituted a neurotic structure, establishing a sort of anaclitic relationship with the objects, displaying a low tolerance to frustration and undergoing significant narcissistic wounds.

Thus, anestructures do not share the same stability and solidity possessed by the so-called "structures". Subjects may seem apparently adapted to reality but when exposed to anxiogenic situations they need to recede to defenses that are more aggressive in order to maintain the cohesion of the ego. Due to premature narcissistic flaws, the individual becomes dependent on external objects to maintain the stability of the Self. The psychic constitution of the individual behaves in an extremely unstable, "wavering" dynamics that is also highly responsive to changes in the environment. Such dynamics enfeeble the subject and assume the status of an organization, as opposed to structure, which presents a higher level of stability.

Another fundamental axis towards the understanding of this dynamics is the conceptualization of character traits. Nevertheless, it is first necessary to discuss character per se, which links to the base structure of a person. Freud (1915/2006) references to "character" or "libidinal types", which are described in three categories. Exceptions, those patients who expect some kind of advantage as compensation for injury experienced in the past. Wrecked by success, subjects who fall ill or punish themselves when they manage to achieve the satisfaction of their desires. And criminals with sense of guilt, which depicts those who due to a prior feeling of guilt commit a crime in search of a punishment capable of alleviating their guilt.

In 1931, Freud mentioned that besides the pathological frameworks already known by then there would be libidinal types encompassing some characteristics of functioning based on the manner by which the dynamics of the libido worked in the mental economics. The first type described by Freud would be the erotic one, in which the larger portion of the libido turns into affective issues, governed by the loss of the object's love. The second one is the obsessive one, which is linked to superego-related issues. The third one is the narcissistic type, which puts self-preservation at the forefront, maintaining a large quantity of aggressiveness at its disposal. Such libidinal types may either manifest themselves in isolation or as a combined cluster, gathering all the above-mentioned characteristics into a single subject. 
Freud paved the way for this subject, and soon others followed him. Fenichel $(1953 / 1981)$ concluded that character seems linked to the functioning of the ego, in a relational and adaptive plan, in accordance with the demands of the internal drives and the outside world. Bergeret shared such position and stated that character translates the manner by which a patient shows himself to others, that is, the interpersonal aspects, which depend on the latent structural characteristics, and are in close correlation to them.

Thus, while character seems to be linked to base structure, character traits correspond to those characteristics found in the subject that are not directly connected to his structure. At times, structures and organizations may use character traits from different structures in order to recoup from character deficiencies. This phenomenon is only possible because during the subject's libidinal drive evolution, prior to the existence of definitive fixations at a given stage, the subject had gone through other libidinal stages and thus he is able to resort to some of their corresponding traits in order to compensate for deficiencies.

Freud referred to this when he debated the character traits corresponding to the anal fixations. He theorized on the origin of character traits in general, assuming that such traits appeared as leftovers of drive fixations, as a form of sublimation or even as a reactive formation. Furthermore, it is worth to highlight that character traits possess no direct relations to any pathology. Compensated structures may present certain character traits as a way to sustain an adapted functioning. Likewise, a structure may use regressive defenses when disorganizing. Thus, character traits are a constituent part of any individual's personality.

\section{THE MELANCHOLIC STRUCTURE}

The term melancholia was employed by Freud in Luto e Melancolia [Mourning and Melancholia] (1917/2006) through a comparative with the state of mourning. According to Freud, both originated from the loss of a dear one or something that had acquired a similar meaning. In melancholia, more specifically, Freud observed that the loss would revive premature childhood losses. While in mourning the subject is aware of exactly what has been lost, in melancholia the loss seems to be one of unconscious nature: the subject is aware that a loss has taken place, but he is not aware of exactly what has been lost.

Freud (1917/2006) established a relation between the symptoms of melancholia and the recurrent symptoms of mourning: discouragement, loss of interest for the outside world, loss of the ability to love, etc. Nevertheless, melancholia displays a peculiar characteristic: loss of self-esteem accompanied by successive self-accusations. The speech of melancholic individuals presents self-accusations and self-depreciation, which in most cases do not truly correspond to the subject 
and possess no concern for exposure or for the possibility of judgment by others. Contrary to what it seems, the self-criticisms of the melancholic individual do not apply to the subject himself. They were originally directed at the object of his love, but were transferred to the ego in order to preserve the affective relationship with that object. By means of a process of identification, the subject incorporates the lost object into the ego and subsequently subjects it to criticism in such way that the criticism seems directed at the subject himself. The ambivalent feelings of the melancholic individual cause him to develop mechanisms to express his loathing for the object without giving up his affective relationship with it. The subject expresses his loathing for the other by speaking of his loathing for himself. The melancholic individual's investment in the dead internalized object becomes central in this pattern at the expense of the ego. Furthermore, although the internalized abandoning object is the main target of attacks, at the same time the subject is also attacking himself. Thus, the sadistic and masochistic aspects of the melancholic structure play a role here.

Hornstein (2006), for instance, approached sadism in melancholia as originating from the superego. Bearing in mind that the superego is formed by parental aspirations and encompasses both the moral consciousness and the ideal of self, at a certain moment the fear of losing the parents' love becomes equivalent to losing the superego's love. The subject's self-esteem is formed through the confirmations he receives from the outside world that he is capable to correspond to his ideal of self, that is, his parental expectations. Therefore, the loss of the superego's love may allow an intense expression of sadism directed towards a masochistic ego. The cruelty of the superego becomes a venue for the expression of the death drive.

The loss of self-esteem, unleashed by the premature loss of the object and subsequently the loss of the superego's love, led Freud (1917/2006) to consider that object choices in melancholia had narcissistic bases. The object of choice is the one that must provide something the subject could not experience with his parental figures during childhood. It is an attempt to repair narcissistic wounds. The finality of object choice is, therefore, the possibility of "being loved". The mechanism of identification and the incorporation of the object into the ego denote an impossibility of separation and a denial of an aspect of reality. The melancholic tries to preserve the object so as not to lose himself.

This pattern points to pre-genital aspects of melancholia. Similarly, Abraham (1924/1970) stated that the bases of melancholia are in the oral-cannibalistic and anal-sadisticstages, prompted by veryearly frustration that gaverise to irreparable narcissistic wounds. Thus, premature experiences of abandonment, whether real or imagined, would mark the origin of melancholia. At a given moment, before the subject had psychic conditions to bear it, a significant disappointment with 
the mother took place coupled with the absence of a paternal figure capable of receiving the demands of care and love coming from the subject. Abraham believed that frustrations concerning the Oedipus complex, when the pre-genital stage mechanisms still find themselves in intense activity, led to an entailment of the Oedipus to the oral-cannibalistic stage, which could partly explain the regressive dynamics found in the melancholic functioning.

The introjection mechanism used by the melancholic subject, typical of the oral stage, allows him to go around the initial losses and get the illusion of recovering the lost object. Abraham also described that the sadistic components of the melancholic subject find roots in the second part of the oral stage (biting, for instance) but are related mainly to the anal-sadistic stage. Sadism, in the case of melancholia, is linked to the first anal stage - the expulsive - due to premature losses and the expression of destructive tendencies towards the object. Theambivalence present in this period strongly underlies themelancholic functioning. The subject now subjugates the object formerly kept close to the ego by means of introjection mechanisms.

Green (1988) pointed out that the melancholic subject's initial bonds prompted the development of the pathology. He postulates that, in the beginning, a bond between mother and child was established, until a certain moment, when for some reason an abrupt maternal disinvestment took place, leaving the child unabletofindan explanationfor theestrangement.Additionally, Greenexplained that if such estrangement by the mother takes place when the child discovers the existence of the third - the father - the child may accuse him of being the cause of the disinvestment, which will make the oedipal triangulation more difficult. Alternatively, the loss of the mother's love may lead to a premature investment in the paternal figure and if the father does not correspond to such demands, the child will feel alone between two abandoning objects.

Bergeret (1998) compiled these aspects, facilitating the clinical identification of the melancholic structure. In the topical point of view there is in melancholia a failure of the ego and the collapse of the ego ideal permeated by an anguish of fragmentation due to the loss of the anaclitic object. The maternal relationship is ambivalent in such way that only its frustrating aspects are preserved alongside the ego while the idealized aspects of the object are linked to the ego ideal. Object relationships take place through aggressiveness, prompting the return of the loathing from the object to the subject himself. The main defense mechanisms in melancholia are the secondary denial after the subject comes to understand reality - the loss of the object - accompanied by the ulterior introjection of this object into the ego.

Due to all of these aspects, as well as due to its pre-genital fixations, Bergeret puts the melancholic structure in the row of psychoses, in-between the schizo- 
phrenic and paranoid ones concerning libidinal development. Even so, the melancholic structure seems to present a superior level of functioning if compared to the other two concerning the maturity of the ego, given that in melancholia libidinal drive development has reached later stages and then receded at a later moment. Thus, the melancholic structure differs from other psychotic structures (which stopped in development, and were trapped in earlier premature stages).

\section{THE PERVERSE ORGANIZATION}

In Três Ensaios sobre a Teoria da Sexualidade [Three Essays on the Theory of Sexuality] (1905/2006), Freud wrote on deviations of the sexual drive in order to introduce the study of perversion. The term perversion encompassed any deviation from the normal sexual activity, that is, from the encounter of the male and female genital organs during the sexual act. Nevertheless, Freud warned that deviations in sexuality are not only found in subjects suffering from some kind of syndrome, but also in those who apparently do not present any other kind of disturbance of mental or social nature. He put in question, therefore, the use of the word "perversion", which could come to be used in an indiscriminate manner since some sort of sexual deviation are found in most individuals, even in those considered neurotic. This sets the prerogative that deviations from the normal sexual activity are found with a certain frequency in subjects who do not necessarily possess a perverse organization of personality.

Thus, what defines perversion is the character of exclusivity and fixation that the deviant sexual target acquires as a representative of the maternal phallus. This means that the object-relations of the perverse individual assume a partial character. Here the relationship with the other can only occur to the extent that the other is the bearer of what the perverse individual desires. This kind of functioning involves a variety of perverse formations such as sadomasochism, pedophilia, voyeurism, exhibitionism, transvestism, fetishism, among others. Fetishism, for instance, makes for a clear demonstration of how the perverse individual elects a partial object that symbolizes the maternal penis, seeking to conceal the castration. Laplanche and Pontalis (1992) reinforced the issue of the polymorphous perverse disposition of the child. Such disposition would be inherent to infantile developmentand in it, the drive would pass through differenterogenous zones, constituting partial objects for a determined period, until the establishing of a total genital relation with the object became possible. In this framework, perversion would be detectable through the regression and fixation of the libido tothese previousstages, that is, through a persistence of polymorphous-perverse traits with partial objects. 
McDougall (1983) depicted the dynamics of the perverse organization. A seductive mother (who maintains an incestuous illusion with the child) and a submissive father represent it. In this case, the child believes, for some time, to be the sole object of maternal desire. The mother herself who performs a splitting that promotes disillusionment. The child, who previously fulfilled the role of maternal phallus, faces the uncertainty of her love while being unable to relate to the father, who lacks the necessary attributes to make him the object of the mother's desire. In this context, the Oedipus complex becomes disorganizing of the child's psyche due to the narcissistic wound prompted by the end of this illusion. This maternal seduction of the child seeks shelter in pre-genital stages, particularly in the anal one. Chasseguet-Smirgel (1991) explored this issue in $O$ perverso $e 0$ ideal do ego [The perverse and the ego ideal], where she pointed out that in perversion the mother allows the child the feeling that he can be a partner regardless of his infantile sexuality. This would absolutely dismiss the paternal figure from its typical role.

Thus, the deviant sexual relation is the path to rescue the narcissism back to the perverse individual and the way he found to retake his place as the maternal symbolic phallus. He rejects a part of reality: he repudiates the maternal castration he previously became aware of and consequently the differences between sexes. It is simply a magical solution in face of castration anxiety.

The perverse organization utilizes the denial of an aspect of reality (the female sex) and makes use of mechanisms in order to maintain this illusion. Even so, the subject may have an adequate functioning concerning every other aspect of his life, as his issues have impact only on this. Bergeret (1998) mentioned the incompleteness of the perverse superego, since the perverse rejects castration. He functions in the level of the ego ideal, that is, he tries at any cost to repair the narcissistic wounds by making use of partial objects, living under the yoke of the immediate satisfaction of his drives.

A perverse organization has as its stage the sexuality, which represents the core around which perverse symptoms take place. From now on, it is essential to highlight this aspect in order to distinguish the perverse organization of personality from character traits of perverse nature, which are not exclusive to this pathology and do not have sexuality as their only venue for manifestation.

\section{MELANCHOLIA, PERVERSION AND CHARACTER TRAITS}

It is possible to identify fundamental differences between a melancholic structure (which figures among psychoses) and a perverse organization (which belongs to the field of anestructures). Tracing a parallel between them, one can observe the presence of anal fixations that will affect these organizations differently. 
Similarly, there are problems related to narcissism. On the other hand, while in perversion the subject rejects a specific part of reality, in melancholia what exists is the denial of the loss of the object, which is introjected into the ego. Although different, both patterns are in service of the reparation of the narcissistic wounds: the perverse tries to retake its place as the maternal phallus, while the melancholic individual preserves the dead object, which performs a narcissistic role.

Our readers can notice that in melancholia, there is a feeling of loss of the object, and that it ends up giving birth to the melancholic character. As for perversion, there is the rejection of castration itself. The perverse mechanism is an escape from depression, which is a base functioning in the case of melancholia. Thus, it is possible for the perverse character mechanism to be found as a character trait in other structures as a defense against the fragmentation anguish.

It is important to highlight the predominance of sadistic and masochistic character traits in both perverse organizations and melancholic structures. In the former, the sexual act is the place where sadism and masochism occur, as Freud postulated (1905/2006). During libidinal development, the erotic and aggressive characteristics walk together for a while. Erotic instincts are related to the preservation of the species and are therefore connected to life. Aggressive instincts, on the other hand, are destructive and were dubbed death drive. Even so, they have an interdependent relation, as the fulfillment of erotic goals often requires, for instance, a certain dose of aggressiveness in order to obtain the desired object. In the case of a perverse organization this aspect becomes even more pronounced since there is disconnecting these functions due to the lack of an authentic superego barrier to contain them. Concerning this issue, Hassoun (2002) stated that in the case of melancholia the distinction and the disentanglement of the death and erotic drives result in the impossibility of a positive development of mourning in the subject. This would explain the perverse cruelty that can be found in the dynamics of a melancholic personality.

In the text Uma criança é espancada [A child is beaten] (1919/2006), Freud wrote on the origins of perversions, sadism and masochism. Freud highlighted beating fantasies that came to surface during the analysis of patients of varied personality structures. He verified a primary trait of perversion present in children who had witnessed episodes of aggression during their childhoods. Such trait may suffer the action, to a lesser or greater extent, of defense mechanisms, configuring different ways of functioning of the personality in adult life and the intensity to which perverse traits will manifest. At first, Freud considered sadism to precede masochism. This conception was later modified (FREUD, 1924/2006). Erogenous masochism - equivalent to the death drive - accompanies the libido during its development states and is prior to sadism. Another form of masochism is then 
added to the erogenous one, namely moral masochism, and the link between masochism and sexual issues is loosened. In moral masochism, suffering is related to an unconscious feeling of guilt possibly originating from a conflict between the ego and the superego and from the perception by the individual that he cannot fulfill his ego ideal. Moral masochism refers to the necessity some people have of suffering because of an unconscious sense of guilt.

Perverse traits of the sadistic and masochistic types are not restricted to deviations of the sexual norm. Freud underlined this idea in his work over the course of several writings. He discussed sadism and masochism within areas other than the sexual one, amplifying their reach to the relational and social fields, as traits of sadism and masochism can be found in several structures and organizations other than the perverse ones:

I know that in sadism and masochism we have always seen before us manifestations of the destructive instinct (directed inwards and outwards), strongly alloyed with erotism; but I can no longer understand how we can have overlooked the ubiquity of non-erotic aggressivity and destructiveness and can have failed to give it its due place in our interpretation of life. (FREUD, 1930, p.66-67).

Moore and Fine (1990) wrote that Freud broadened his concept of perversion over the course of his work and concluded that conscious and unconscious sadomasochistic rewards are involved in many different kinds of behavior: provocation, sarcasm, buffoonery, slander and passive aggressions of all sorts.

Zimerman (1999), on the other hand, worked on the etymology of the word "perversion" to explain that the term expresses attitudes that upset the order of things and consequently challenge the law. Thus, he stated that the term perversion connects to the moral, social and institutional fields, among others. While other authors kept their focus on the classic concept of perversion, related to sexuality, nowadays the concept is as a subversion of interpersonal relations in general. It is by means of this perspective that it becomes possible to understand the intense presence of traits of perverse nature in other structures such as in melancholia.

In O Ego e o Id [The Ego and the Id] (1923) Freud explained that due to the journey through the Oedipus complex there is a detachment of part of the aggressive instinct from the erotic instinct, with the former being directed to a lesser or greater degree to the constitution of the superego. This takes place after the Oedipus complex and would encompass part of the aggressive drive, which can be directed at the outside world through sadism and may be directed at the ego through the death drive, establishing a masochistic state. In this case, the perverse traits of melancholia, differently from the perverse organization, have a strong connection to a tyrannical superego. 
The intensity of a child's superego will be based on the severity to which the subject has been subordinated during childhood. In contrast, the vindictive aggressiveness directed at the parental figures will also play a role (which the subject has had to contain within himself). The latter originates partly from the unconscious feeling of guilt existent in each subject.

In the case of melancholia, there is the aggravating circumstance of premature abandonment, which is seem as the loss of the love from the parental figures and, subsequently, the loss of the love from the superego. This presupposes that the child was not able to fulfill parental expectations, that is, he could not meet the exigencies of his ideal of self. This process intensifies the masochistic manifestations of the ego. Furthermore, due to the very mechanism of incorporation of the abandoning object into the ego, typical of the melancholic structure, sadism - which would be directed at the object — ends up relapsing on the self.

The sentiment of joy in melancholia is obtained through the speech of lamentation directed at the other. McWilliams (2011) states that it is possible to observe certain satisfaction in personalities of masochistic character when they are speaking of their history of failures, as it somehow also channels the subject's sadism since it slanders those who mistreated him. Thus, they feel pleasure in exposing their misery since there is a secondary gain in the discourse. In this sense, one can think of the deviation of drive satisfaction present in melancholia also as a perverse trait, as joy in this case is only possible through the melancholic discourse externalized to others.

\section{CLINICAL ILLUSTRATION}

We offer here the case of a patient with a melancholic structure. The aim is to clarify the perverse traits in her dynamics. Her name and family's data were modified in order to respect ethical issues. The patient has signed a term of agreement where she authorized the use of her clinical data in this study.

Sarah, 42 years old, married, sought treatment spontaneously. Her declared motives were to better deal with facts in her history that she believed were interfering in her relationship with her 14-year-old son, Lucas. Over a year had passed since Sarah's mother had passed away, and she was still showing residues of the mourning process.

She presented a discourse permeated by feelings of grief and failure that did not appear connected to the loss of her mother. She was unable to define exactly what those feelings were about although she associated them with her childhood. She showed resentment towards her father and two brothers and an affective ambivalence towards her mother. She was unable to have a good relationship with her family. She claimed she could not even look in the mirror, 
for she resembled them. She avoided, and at certain moments outright refused, to talk about her history.

Sarah had a post-graduation degree, but she only worked in positions far below her educational background. She was gifted with intelligence and critical thinking. She claimed to feel pressured by her husband to look for a working position to which she felt inapt.

Little by little, it became possible to identify melancholic aspects in Sarah:

"You know, I think I need to learn how to live with my sadness. The truth is I do not know whether it will pass. However, I need to look at it and say 'well, you are going to stay here beside me, and I will go on doing my things without letting you bother me'. Simply ignore its existence and live my life with it right beside me."

Sarah had been undergoing treatment for seven months when she received news that her husband, who had been traveling on business, had had a boat accident in a river in the region they lived in and had gone missing. He had drowned.

Relationship conflicts with her husband's family surfaced along with his dead body, particularly with her mother-in-law, towards whom she harbored resentment. This fact evidenced her melancholic character in association with a new mourning process. Along with the suffering caused by the loss of her husband, her feelings of abandonment came to the fore, as well as her conflicts concerning the abandonment by her family. The presence of her therapist at this core moment was important to reinforce her adherence to treatment.

The following months were very difficult for Sarah. Although she worried about her son, she could not get as close to him as before. She said it was supposed to be the role of a father to raise him during adolescence and that she was the one who should have died, not her husband.

"You know that actress who killed herself one of these days because she lost her beloved? People became horrified seeing that. I can understand why she committed suicide. I have already felt like doing the same thing. The only reason I have not done it is Lucas. I can't even kill myself because then I would abandon my son, just like they did to me."

The factual loss of her husband unleashed an intense process of self-depreciation. She felt guilty for his death, as if it were a punishment. Her husband was treated in an idealized fashion. He was praised for "having agreed to marry a woman like her", with a background she so despised. She regretted "not having been a better wife for him".

The figure of her husband, which prior to his passing had been a target of her frustrations, now became idealized and overinvested, which is a natural mechanism of mourning. What was out of tune, however, was Sarah's selfcriticism that surfaced concomitantly and did not seem to bear any plausible 
justification on reality. In this case, her self-depreciation corresponded to the loss of self-esteem typical of the melancholic structure, which takes place through the projection of loathing towards the frustrating and abandoning object that has been incorporated into the ego of the patient. Consequently, the resulting aggression falls upon the subject himself, establishing a masochistic pattern.

Her relationship with her husband had an important meaning for it evidenced the narcissistic character of her choice. He enabled her to build a different family from the one she had had. Sarah said she felt "protected in his presence". She frequently described the care he had for her, similar to the care she wished she had received in her childhood. The narcissistic content and the fear of loss and abandonment were evident in her discourse:

"I feel a never-ending sadness because now I think I miss him more than ever... I think I am starting to realize he is not coming back. It has been a year now... In addition, I am starting to ask myself if it is not an illness to feel like this because of the beloved. I feel such sadness and I do not want Lucas to realize I am like this... It seems that he is already grown up now; he is a huge man, bigger than I am, and he does not need as much care as before... Soon he will have his own life, a girlfriend, and he will not be forever by my side... After my beloved passed away, I cannot take care of my son anymore. Moreover, I was not like this. I think he fulfilled this role for me. He took care of me. It was so good when I got home and he was there waiting for me..."

After some time of treatment, her therapist, for private reasons, had to move to another city. This was approached during the sessions so that, to the extent that it was possible, the patient would not interpret it as a repetition of the successive episodes of abandonment in her history. She manifested the will to travel to her therapist's new city (which was located about $300 \mathrm{~km}$ away from the city where Sarah lived) in order to continue the treatment. In addition to fear of abandonment, this suggested the need to preserve a bond as well as showed some possibility of an investment in building a different kind of relationship. From this momenton, Sarah kept traveling weekly to theappointments, although during the sessions she always put in question whether she would return for the next session and kept monitoring and expecting a reaction from the therapist to this "threat" of abandonment of treatment.

She began outlining events of her life that she so despised. Her speech evidenced that her father had a perverse organization of personality. She referred to episodes of physical aggression and sexual abuse experienced during her childhood. She reported an episode where her father woke his children up at night, ordered them to undress and beat them for no apparent reason. He used to employ of a horsewhip for that. Sarah described herself as a sad girl who sulked through the corners of the house, in deep fear, trying not to be noticed 
in order to escape from her father's fury and lust. He had a special interest in her elder sister whom, according to Sarah, was very beautiful.

Sometimes Sarah was left alone, as her sister was the center of her father's attentions. She told about circumstances when her father took her out for a walk and he came to forget her in different places. She longed for his attention. She liked when he occasionally invited her to watch television sitting on his lap. She said she had been "spared" until she turned seven, when her father started to "notice" her. She mentioned, without getting into much detail, episodes when her father lay in bed with her and molested her. This subject was never broached within the family.

She described hermother as a neglectful figure.Contradictorily sheattributed to her mother whatever little affection shehad received. She believed her mother must have taken care of her "a little", since she "was able to develop feelings" for her son and to be affective with him and her husband. Nevertheless, she used to say she had "not a memory of even a single moment of affection her mother had had towards her". She said:

"I don't remember my mother ever giving me a hug or putting me on her lap. I do not know whether she did so. From what I remember, she did not. After I left home, she started coming to visit me and she would hug me when she arrived at my place. I noticed then that I did not really know what to do. I could not answer that hug, as if I didn't know how because I had never had that."

It was a setting of abandonment and feeling of loss, ideal for a melancholic configuration. There was a mother who had been present but retreated too soon and a father to whom it was impossible to direct her requests of love, for it came along with the risk of fulfilling the incest. Sarah, unable to confront a typical oedipal scene and due to severe narcissistic injury, sought protection in a movement towards pre-genitality:

"Sometimes I wonder if I'll ever like myself. I look at myself and I see a resemblance with my father. I think I cannot like my siblings as well because I see something of my father in each of them. This will end up undermining my relationship, as Pedro - her new boyfriend - is very annoyed at how often I ask him if he loves me. It seems that even if he repeatedly states that he does, I cannot believe it. I do not want to lose him."

At school, she had no friends and suffered bullying in a regular basis. In her adolescence, what she wanted most was to be able to work and "leave home". At sixteen, she found a job and left home.

A year later, approximately, she met her husband. She claimed to have fallen in love "at first sight". They got married and had Lucas. She built her own family but her underlying feeling of failure and sadness persisted as well as her conflicts concerning her original family. 
She described herself as an emotive and sensitive person but she failed to understand why she could not be affective with her siblings. She gave them names, with the exception of the eldest brother, David, to whom she could relate since "he had worked and built a stable family". Sarah repeatedly classified her siblings as "the bipolar", "the alcoholic", "the trickster", and, in the case of the youngest sister, "the whore". She was ashamed of her family.

This kind of behavior caused her to be named "the evil one" by her family members. Her friends were shocked by the cruelty shown by Sarah. She was gifted with a sharp critical sense and had no scruples when throwing caustic remarks at people. Her remarks were aligned with reality but they acquired a perverse character due to the manner by which she distilled and proffered her criticisms. She showed pleasure to people's reactions. She failed to notice any inadequacy in her behavior since she "hated hypocrite people".

In truth, this hate was directed at her parents. The need to criticize people suggested a desire to confront her father, the legitimate representative of hypocrisy in her childhood. It also suggested, at the same time, identification with him as an aggressor. Sarah criticized others and downplayed her own merits, and yet could not get rid of the role of sufferer in her own history. Sarah herself was the person she wanted to unmask.

She would either undergo a state of self-accusations, her speech permeated by feelings of failure and low self-esteem, or project those components onto people she lived with, criticizing them with the same intensity with which she belittled herself. This attack mechanism seemed, to a certain degree, to preserve Sarah's ego, since when the ego's masochism overflowed, the superego's aggression would be directed at the outside world in a perverse movement. One can observe that the mechanisms of introjection of the abandoning object caused the aggression towards the object to be redirected to the Self. In addition to this, there were unconscious feelings of guilt, which could have had their origins both in the fact that the patient tried to attack the abandoning objects and in the fact that she felt they would not correspond to the ego ideal.

Guilt became more evident after a session in which oedipal contents arose: her desire to have received the paternal "love" which was aimed at her sister, and her rivalry with her sister, which lasted up to her adult life. These aspects surfaced in an e-mail message sent by Sarah to her therapist.

"I dreamed of my father. I dreamed that he kissed me and beat me, that he was part of my life however much I did not want it... Disintegrating is the only way, because vanishing would not do it... I have to tell you, I fear you might say things I would not want to hear. Things like 'you like your father and the abuses he used to commit against you'. I do not know whether I will have the courage to go on, it hurts a lot to talk about what I feel for my father. I cannot 
accept many things. I feel even guiltier and even angrier with myself. And thus it's hard for me to accept myself, to love myself."

The text showed that such contents revealed her guilt for having desired her father. The possibility of having felt pleasure in that setting of abuse drove away from Sarah the chance to feel pleasure in life, except the pleasure felt through her discourse oflamentation, which satisfied her sadisticand masochisticcomponents.

Sarah described two other dreams in the following sessions. In the first, she was enjoying her relationship with her boyfriend and she felt happy. In the second, she had retaken her relationship with her sister. Such dreams could be positive clues, showing the possibility of forming new bonds and repairing old ones. At the same time, it could be interpreted that in the first dream, her boyfriend represented her father, and she admitted feeling happy in his presence. The second dream could represent her forgiveness of her sister for having been the sister who was chosen by her father in her place.

Sarah showed she had noticed these traits, fruits of a rigid superego, which drove away the possibility of experiencing pleasure any other way. She believed that all her feelings of failure and grief came from the difficulty to love herself, since she had never felt loved by her parents.

After over two years of treatment, Sarah still says she is not satisfied with the image reflected in the mirror, but she is already able to look at the pictures she kept from her childhood. She noticed the vulnerability of that girl in the photography and concluded that at that time she had had no opportunity to choose. Sarah still does not allow herself to enjoy the recent accomplishments in her life, a life that is still marked by sadness and the melancholic discourse of insolubility.

\section{FINAL CONSIDERATIONS}

Sarah's case demonstrated how perverse character traits could be active in a melancholic structure. This gives rise to reflections on the need to identify dynamic aspects that are crucial for the correct diagnosis. This process can be a facilitator in our comprehension of the subject and goes well beyond the classification in a determined category.

Our bibliographical review allowed us to verify that perverse character traits permeate several structures of personality and anestructures. They are not restricted to a perverse organization perse. The polymorphous-perverse stage and the factual abuse and/or abuse fantasies show that some degree of perversion is a constituent part of the subject's development and could manifest itself well into adult life, depending on the fixations undergone by the libido.

The broadening of the concept of perversion from the sexual field to the social and relational fields enabled a better understanding of the manifestation 
of perverse traits. The case of Sarah is a typical example of how they can be part of a melancholic structure forming a path for the satisfaction of the libido. The satisfaction of the subject lies in complaining to others. In addition, their displeasure in hearing gives a possibility of pleasure to the melancholic individual.

Melancholic self-depreciation constitutes at the same time a sadistic move against the abandoning object and a masochistic move, as it reflects on the ego of the subject who incorporated the object. In addition, abandonment is faced as the loss of love. It generates feelings of guilt in the subject, who feels responsible for not corresponding to an ego ideal, intensifying the sadism of the superego towards the masochistic ego.

Theabuses suffered by Sarah made possible to identify theactivechild beating scenes. The guilt born from her desire for her father was intensified by the fact that he fulfilled the incest, as if the child's desire for the father had promoted the abuse. When these feelings became too intense, the patient employed a movement of projection by which she directed the aggressive drive towards the outside world.

This study has approached Sarah's case under a specific lens without exhausting the subject. It is important to highlight that due to the richness of the material produced in the case other authors could tackle the issue from a different approach. Nevertheless, here is provided the idea that the functioning of a personality, under certain circumstances, has little to do with its base structure, and this should be taken into consideration by the therapist during the process of assessment the patient. Winnicott (1983) and Bastos (2014) stated that one of Freud's largest contributions to the understanding of patients was the need to move beyond classification. We should probe our understanding of three extremely relevant aspects: the person's behavior toward and relation with reality; the formation of the symptoms, understood as a form of communication of the unconscious; and the etiology, which values the history of the patient his family, and the material emerging during the course of the treatment.

Recebido/Received: 14/4/2014. Aprovado/Accepted: 15/1/2015.

\section{REFERENCE LIST}

ABRAHAM, K. (1970). Teoria Psicanalítica da libido [Psychoanalytic theory of libido]. Rio de Janeiro: Imago.

BASTOS, A.G. (2014). Diagnóstico psiquiátrico e clínica psicanalítica [Psychiatric diagnosis and clinical psychoanalysis]. Interação em Psicologia 18(1), pgs.109-117.

BERGERET, J. (1998). Personalidade normal e patológica [Normal and pathological personality]. Porto Alegre: Artes Médicas. 
FENICHEL, O. (1981). Teoria psicanalítica das Neuroses [Psychoanalytic Theory of Neurosis]. Rio de Janeiro: Atheneu.

FREUD, S. (2006) Obras psicológicas completas de Sigmund Freud: Edição standard brasileira [Complete Psychological Works of Sigmund Freud: Brazilian standard Edition]. Rio de Janeiro: Imago.

(1905) "Três Ensaios sobre a Teoria da Sexualidade" [Three Essays on the Theory of Sexuality], Vol. VII, p.117-166.

(1908) "Caráter e erotismo anal" [Character and anal eroticism], Vol. 9, p. 159-164.

(1915) "Algunstipos decaráter destacadospelapsicanálise" [Sometypes of character highlighted by psychoanalysis], Vol. XIV, p. 325-348.

(1917) "Luto e Melancolia" [Mourning and Melancholia], Vol. XIV, p. 249-263.

(1919) "Uma criança é espancada" [A child is being beaten], Vol. XVII, p. 195-218.

(1924) "O problema econômico do masoquismo" [The economic problem of masochism], Vol. XIX, p. 177-188.

(1931) "Tipos libidinais" [Libidinal types], Vol. XXI, p. 225-228.

(1932-1936) "Novas conferências introdutórias sobre psicanálise" [New Introductory Lectures on Psychoanalysis], Vol. XXII, p. 13-177. (1932) "Por que a guerra?" [Why war?], Vol. XXII, p. 191-197.

GREEN, A. (1988) Narcisismo de morte [Narcissism of death]. São Paulo: Escuta.

HASSOUN, J. (2002). A crueldade melancólica [The melancholy cruelty]. Rio de Janeiro: Civilização Brasileira.

HORNSTEIN, L. (2006). Las Depresiones: afectos e humores del vivir [Depressions: Emotions and moods of living]. Buenos Aires: Paidós.

MCDOUGALL, J. (1983). Em defesa de certa anormalidade: teoria e clínica psicanalítica [Defending a certain abnormality: Psychoanalytic theory and clinics]. Porto Alegre: Artes Médicas.

MOORE, B. E.; FINE, B.D. (1992) Termos e conceitos psicanalíticos [Terms and concepts in psychoanalysis]. Porto Alegre: Artes Médicas.

WINNICOTT, D. W. (1983). O ambiente e os processos de maturação [The maturational processes and the facilitating environment]. Porto Alegre: Artes Médicas

ZIMERMAN, D. E. (1999) Fundamentos psicanalíticos: teoria, técnica e clínica [Psychoanalytic fundaments: Theory, technique and clinics]. Porto Alegre: Artmed.

Larissa Bastiani Roggia

larissabastiani@hotmail.com

André Goettems Bastos

andregbastos@gmail.com

Traduzido do português por Giovani Bastiani Roggia/translated from portuguese by Giovani Bastiani Roggia 